\title{
LITERASI INFORMASI MASYARAKAT PEDESAAN DALAM PROGRAM PEMBERDAYAAN MASYARAKAT DI KECAMATAN CIKANCUNG BANDUNG
}

\author{
Ninis Agustini $\mathrm{D}^{1}$, Tine Silvana $\mathrm{R}^{2}$, Agung Budiono ${ }^{3}$, Encang Saepudin ${ }^{4}$ \\ ${ }^{1,2,3,4}$ Program Studi Ilmu Informasi \& Perpustakaan \\ ${ }^{1}$ ninis.agustini@unpad.ac.id, ${ }^{2}$ tine.silvana@unpad.ac.id, ${ }^{3}$ agung.budiono@unpad.ac.id, \\ ${ }^{4}$ encang.saepudin@unpad.ac.id
}

ABSTRACT - This research was aimed to investigate the information literacy of rural communities on society empowerment at Cikancung Sub-District, Bandung Regency. Particularly the research was aimed to find out the information literacy level of the rural communities on planning, implementing, utilization and evaluating program. Mixed methods was used in the research, while data was gained from questioner, focus group discussion, interview, observation and literature studies. First benefit of the research was an evaluation form of implementation goverment policy. Second benefit was that the form could be useful input for the government of Bandung Regency, especially for BKPPP in implementing food self-sufficient village program. The result of the research indicated that the information literacy level of the rural communities on planning, implementing, utilization, and evaluating program was positive. It meant that the rural communities were already literate. The result was based on statistical calculation, which showed that median value less than score value, and the score value less than quartil value III. So that it could be concluded that the rural communities were already literate towards the government program of society empowerment.

Keywords: Information Literachy, Society Empowerment, Rural Communities

ABSTRAK - Penelitian ini mengkaji tentang Literasi Informasi Masyarakat Pedesaan dalam Program Pemberdayaan Masyarakat Di Kecamatan Cikancung Kabupaten Bandung. Dengan menggunakan metode gabungan mixed methods dan teknik pengumpulan data melalui penyebaran angket, wawancara, FGD, observasi, dan studi pustaka, penelitian ini bertujuan untuk mengetahui tingkat Literasi masyarakat pedesaan pada tahap perencanaan, pelaksanaan, pengambilan manfaat, dan evaluasi program pemberdayaan masyarakat. Manfaat penelitian ini yakni sebagai bentuk evaluasi program terutama terhadap implementasi kebijakan pemerintah. Selain itu, Sebagai masukan bagi pemerintah Kabupaten Bandung terutama Badan Ketahanan Pangan dan Pelaksana Penyuluhan (BKPPP) Kabupaten Bandung dalam mengiplementasikan program desa mandiri pangan. Hasil penelitian menunjukkan tingkat literasi masyarakat pedesaan baik pada tahap perencanaan, pelaksanaan, pengambilan manfaat, dan evaluasi program pemberdayaan dapat dikategorikan positif artinya masyarakat sudah literat. Hal ini didasarkan pada hasil perhitungan statistik yang menggambarkan bahwa nilai median lebih kecil dari nilai skor dan nilai skor lebih kecil dari nilai kuartil III. Berdasarkan hasil pengolahan data, penelitian ini dapat disimpulkan bahwa Masyarakat Di Kecamatan Cikancung Kabupaten Bandung sudah literat terhadap program pemberdayaan masyarakat.

Kata kunci: Literasi Informasi, Pemberdayaan Masyarakat, Masyarakat Pedesaan

\section{PENDAHULUAN}

Menurut Sartono Kartodirjo dalam Hari Poerwanto (2000: 197), mengemukakan bahwa sebagian besar masyarakat desa di Indonesia diliputi oleh sindrom kemiskinan dan sindrom enersia. Sindrom kemiskinan memiliki dimensi yang amat komplek dan satu dengan yang lainnya saling berkaitan, misalnya dalam bentuk tingkat produktivitas yang rendah, pengangguran, kurang gizi dan derajat kesehatan yang buruk, tingkat morbiditas dan buta huruf yang tinggi. Sementara 
itu sindrom enersia terwujud pada sikap fatalisme, passivisme, rasa saling ketergantungan yang tinggi, kehidupan serba mistik dan sebagainya. Jika dikaji lebih lanjut, kedua jenis sindrom tadi diakibatkan oleh berbagai faktor yang saling berkaitan, antara lain ketimpangan pemilikan dan distribusi tanah, pelapisan sosial yang rancu, kurangnya pemanfaatan sumber daya dan sebagainya.

Salah satu upaya untuk mengatasi masalah kerawanan pangan dan kemiskinan di pedesaan adalah melalui Program Desa Mandiri Pangan. Desa Mandiri Pangan adalah desa yang masyarakatnya mempunyai kemampuan untuk mewujudkan ketahanan pangan dan gizi sehingga dapat menjalani hidup sehat dan produktif dari hari kehari, melalui pengembangan sistem ketahanan pangan yang meliputi subsistem ketersediaan, subsistem distribusi, dan subsistem konsumsi dengan memanfaatkan sumberdaya setempat secara berkelanjutan. Upaya tersebut dilakukan melalui proses pemberdayaan masyarakat untuk mengenali potensi dan kemampuannya, mencari alternatif peluang dan pemecahan masalah serta mampu mengambil keputusan untuk memanfaatkan sumberdaya alam secara efisien dan berkelanjutan sehingga tercapai kemandirian.

Program Desa Mandiri Pangan dilaksanakan selama 4 (empat) tahap berturut-turut. Melalui 4 tahapan pelaksanaan yakni tahap persiapan, penumbuhan, pengembangan, dan kemandirian. Tiap tahapan memuat berbagai macam kegiatan dengan waktu pelaksanaan tiap tahapan adalah selama satu tahun. Kegiatan difokuskan di daerah rawan pangan dengan mengimplementasikan berbagai model pemberdayaan masyarakat dalam mewujudkan ketahanan pangan yang telah ada di tingkat desa dengan melibatkan seluruh Literasi informasi masyarakat. Pemberdayaan masyarakat dilakukan dengan menempatkan tenaga pendamping di setiap desa pelaksana selama empat tahun berturut-turut mulai dari tahap persiapan, penumbuhan, pengembangan dan kemandirian.

Permasalahan dan tantangan dalam pembangunan ketahanan pangan secara umum menyangkut pertambahan penduduk, semakin terbatasnya sumber daya alam, beralihfungsinya lahan pertanian, masih terbatasnya prasarana dan sarana usaha di bidang pangan, semakin ketatnya persaingan pasar dengan produk impor, dan besarnya proporsi penduduk miskin.

Penduduk miskin yang rawan pangan serta rentan terhadap masalah kerawananan pangan masih cukup tinggi. Penyebab utama kerawanan pangan dan kemiskinan adalah rendahnya pendapatan masyarakat miskin yang mengakibatkan daya beli masyarakat berkurang. Keterbatasan kemampuan masyarakat dalam mengakses pangan; serta keterbatasan aset dan akses terhadap sumber daya untuk mengembangkan usaha mikro.

Kerawanan pangan terjadi manakala rumah tangga, masyarakat atau daerah tertentu mengalami ketidakcukupan pangan untuk memenuhi standar kebutuhan fisiologis bagi pertumbuhan dan kesehatan para individu anggotanya. Kerawanan pangan dibedakan atas kerawanan kronis, yaitu yang terjadi terus menerus karena ketidakmampuan membeli atau memproduksi pangan sendiri, dan kerawanan 
sementara yang terjadi karena kondisi tak terduga seperti bencana alam atau bencana lainnya. Kerawanan pangan, apabila terjadi terus menerus, akan berdampak pada penurunan status gizi dan kesehatan. (Pedum MAPAN 2012).

Kemiskinan adalah situasi serba kekurangan yang terjadi bukan karena dikehendaki si miskin, melainkan karena tidak dapat tidak dapat dihindari oleh kekuatan yang ada padanya. Inti daripada devenisi ini adalah situasi serba kekurangan yang tidak dapat dihindari oleh si miskin. (Mubyarto, dalam Safi'i (2011: 24).

Penduduk miskin ini memiliki resiko tinggi dan rentan mengalami kerawanan pangan. Apabila program-program pemantapan ketahanan pangan kurang memperhatikan kelompok ini maka akan berdampak meningkatkan kemiskinan/kerawanan pangan dan status gizi yang rendah. Kerawanan pangan terjadi manakala rumah tangga, masyarakat atau daerah tertentu mengalami ketidakcukupan pangan untuk memenuhi standar kebutuhan fisiologis bagi pertumbuhan dan kesehatan para individu anggotanya. Kerawanan pangan dibedakan atas kerawanan kronis, yaitu yang terjadi terus menerus karena ketidakmampuan membeli atau memproduksi pangan sendiri. Selain itu, kerawanan sementara yang terjadi karena kondisi tak terduga seperti bencana alam atau bencana lainnya. Kerawanan pangan, apabila terjadi terus menerus, akan berdampak pada penurunan status gizi dan kesehatan.

Perwujudan ketahanan pangan nasional dimulai dari pemenuhan pangan di wilayah terkecil yaitu pedesaan sebagai basis kegiatan pertanian. Basis pembangunan perdesaan bertujuan untuk mewujudkan ketahanan pangan dalam suatu wilayah yang mempunyai keterpaduan sarana dan prasarana dari aspek ketersediaan, distribusi dan konsumsi pangan untuk mencukupi dan mewujudkan ketahanan pangan rumah tangga. Disamping itu membangun daerah pedesaan sangat penting terutama dalam hal penyediaan bahan pangan untuk penduduk, penyedia tenaga kerja untuk pembangunan, penyedia bahan baku untuk industri, dan penghasil komoditi untuk bahan pangan dan ekspor. Karena itu, desa merupakan salah satu entry point untuk masuknya berbagai program yang mendukung terwujudnya ketahanan pangan di tingkat rumah tangga, yang secara kumulatif akan mendukung terwujudnya ketahanan pangan di tingkat kabupaten/kota, propinsi, dan nasional.

Berdasarkan uraian diatas maka masalah yang diangkat akan dirumuskan dalam bentuk pertanyaan penelitian, yaitu: Sejauhmana Literasi informasi masyarakat pada program desa mandiri pangan di Desa Mekarlaksana Kec. Cikancung Kabupaten Bandung?

Berdasarkan kepada rumusan masalah maka tujuan penelitian ini adalah Untuk Mengetahui Literasi informasi masyarakat pada tahap pengambilan keputusan/ perencanaan, pelaksanaan program, pengambilan manfaat, dan evaluasi dalam program desa mandiri pangan di Desa Mekarlaksana Kec. Cikancung Kabupaten Bandung.

\section{TINJAUAN PUSTAKA}

Program Desa Mandiri Pangan adalah program pembangunan yang bersifat partisipatif yang mengamanatkan adanya pelibatan 
masyarakat secara aktif pada setiap tahapan kegiatan, yang mengarah pada bertemunya pendekatan pembangunan top down dan bottom up. Secara riil operasional program baik dalam penentuan lokasi dan operasional awal pelaksanaan program terdapat kesenjangan karena masih menggunakan pendekatan pembangunan yang bersifat top down dalam artian, proses perencanaan, penentuan lokasi, penentuan tahapan kegiatan dan pelaksanaan program awal belum sepenuhnya melibatkan Literasi informasi masyarakat. Peran dan Literasi informasi masyarakat berupa tinjauan dan komentar terhadap program merupakan peran yang paling sederhana dari masyarakat belum muncul, sehingga dikhawatirkan dukungan dan rasa memiliki masyarakat terhadap program tidak akan muncul yang berimbas pada capaian program yang kurang maksimal.

Implementasi program pembangunan ketahanan pangan dilaksanakan dengan memperhatikan sub sistem ketahanan pangan yaitu: (a) sub sistem ketersediaan pangan melalui upaya peningkatan produksi, ketersediaan dan penanganan kerawanan pangan, (b) sub sistem distribusi pangan melalui pemantapan distribusi dan cadangan pangan, serta (c) sub sistem konsumsi pangan melalui peningkatan kualitas konsumsi dan keamanan pangan. Dengan demikian, program-program pembangunan pertanian dan ketahanan pangan tersebut diarahkan untuk mendorong terciptanya kondisi sosial, budaya, dan ekonomi yang kondusif, menuju ketahanan pangan yang mantap dan berkelanjutan.

\section{METODE PENELITIAN}

Metode yang digunakan dalam penelitian ini adalah metode mixed methods. Penelitian ini merupakan suatu langkah penelitian dengan menggabungkan dua bentuk penelitian yang telah ada sebelumnya yaitu penelitian kualitatif dan penelitian kuantitatif. Menurut Creswell (2010: 5), penelitian campuran merupakan pendekatan penelitian yang mengkombinasikan antara penelitian kualitatif dengan penelitian kuantitatif.

Dalam penelitian ini menggunakan strategi metode campuran sekuensial/ bertahap (sequential mixed methods) terutama strategi eksploratoris sekuensial. Sequential explanatory designs, pengumpulan data kuantitatif dan kualitatif dilaksanakan dalam dua tahap, dengan penekanan utama pada metode kuantitatif.

Untuk menghindari terjadinya kesalahan atau bias pemaknaan dan juga perbedaan persepsi tentang definisi masing-masing variabel yang digunakan, maka peneliti menganggap perlu menjelaskan definisi masing-masing variabel tersebut. 


\begin{tabular}{|c|c|c|c|c|}
\hline \multicolumn{5}{|c|}{ Tabel 1 Operasional Variabel } \\
\hline Variabel & $\begin{array}{l}\text { Sub } \\
\text { variabel }\end{array}$ & Indikator & Skala & $\begin{array}{l}\text { No.It } \\
\text { em }\end{array}$ \\
\hline \multirow[t]{4}{*}{$\begin{array}{l}\text { Literasi } \\
\text { informas } \\
\text { i } \\
\text { Masyara } \\
\text { kat }\end{array}$} & $\begin{array}{l}\text { Literasi } \\
\text { informasi } \\
\text { Masyara } \\
\text { kat } \\
\text { dalam } \\
\text { Pengamb } \\
\text { ilan } \\
\text { Keputusa } \\
\text { n/ } \\
\text { Perencan } \\
\text { aan }\end{array}$ & $\begin{array}{l}\text { Peroleh } \\
\text { informasi } \\
\text { Kejelasan } \\
\text { informasi } \\
\text { pencarian } \\
\text { informasi } \\
\text { lebih jauh } \\
\text { Ikut serta } \\
\text { dalam } \\
\text { musyawara } \\
\text { n } \\
\text { MemberI } \\
\text { masukan } \\
\text { ide/ } \\
\text { gagasan } \\
\text { mengikuti } \\
\text { seluruh } \\
\text { progran }\end{array}$ & Ordinal & $6-11$ \\
\hline & $\begin{array}{l}\text { Literasi } \\
\text { informasi } \\
\text { Masyara } \\
\text { kat } \\
\text { dalam } \\
\text { Pelaksan } \\
\text { aan } \\
\text { Program }\end{array}$ & $\begin{array}{l}\text { Alat usaha } \\
\text { milik } \\
\text { pribadi. } \\
\text { Pendokum } \\
\text { entasin } \\
\text { hasil } \\
\text { kegiatan } \\
\text { Selalu ikut } \\
\text { serta dalam } \\
\text { pengadmin } \\
\text { istrasian } \\
\text { Peran } \\
\text { Fasilitator }\end{array}$ & Ordinal & $12-16$ \\
\hline & $\begin{array}{l}\text { Literasi } \\
\text { informasi } \\
\text { Masyara } \\
\text { kat } \\
\text { dalam } \\
\text { Pengamb } \\
\text { ilan } \\
\text { Manfaat }\end{array}$ & $\begin{array}{l}\text { Adanya } \\
\text { program } \\
\text { desa } \\
\text { mandiri } \\
\text { pangan } \\
\text { membantu } \\
\text { pemecahan } \\
\text { masalah } \\
\text { Keterampil } \\
\text { an anggota } \\
\text { kelompok } \\
\text { meningkat }\end{array}$ & Ordinal & $\begin{array}{l}17- \\
18\end{array}$ \\
\hline & $\begin{array}{l}\text { Literasi } \\
\text { informasi } \\
\text { Masyara } \\
\text { kat } \\
\text { dalam } \\
\text { Evaluasi }\end{array}$ & $\begin{array}{l}\text { Memberik } \\
\text { an } \\
\text { masukan } \\
\text { kepada } \\
\text { pengelola } \\
\text { program } \\
\text { Membantu } \\
\text { dalam } \\
\text { pengumpul } \\
\text { an data }\end{array}$ & Ordinal & $19-20$ \\
\hline
\end{tabular}

Populasi adalah wilayah generalisasi objek/subjek yang memiliki kualitas dan karakteristik tertentu yang ditetapkan oleh peneliti untuk dipelajari dan kemudian di tarik kesimpulan. Populasi dalam penelitian merupakan sumber data yang terdiri dari sekelompok subjek, gejala atau objek. Hal ini sesuai dengan pendapat Prijana $(2005,4)$ yang mengemukakan bahwa, "Populasi adalah keseluruhan unit-unit observasi yang karakteristiknya akan diduga“. Yang menjadi populasi dalam penelitian ini adalah Masyarakat yang tergabung dalam kelompok afinitas di Desa Mekarlaksana Kecamatan Cikancung. Ukurang populasi penelitian ini adalah seluruh anggota afinitas dengan jumlah 180 orang.

Sampel adalah bagian dari jumlah dan karakteristik yang dimiliki oleh populasi tersebut. Yang menjadi populasi dan sempel dalam penelitian ini adalah Masyarakat yang tergabung dalam kelompok afinitas di Desa Mekarlaksana Kecamatan Cikancung.

Untuk dapat menentukan jumlah sampel dan agar sampel yang diambil dapat mewakili keseluruhan populasi (representatif) maka digunakanlah teknik pengambilan sampel (sampling) simple random sampling (Sampel acak sederhana), hal ini disebabkan jenis populasi yang relatif homogen atau sama (Sugiyono 2011, 82).

Untuk memperoleh ukuran sample yang representatif, maka penulis menggunakan rumus Taro Yamane, yaitu sebagai berikut:

$$
n=\frac{\mathrm{N}}{\mathrm{Nd^{2 } + 1}}
$$

Keterangan: 
$\mathrm{n}$ : jumlah sample

$\mathrm{N}$ : jumlah populasi

d : tingkat perkiraan kesalahan $10 \%$

(Jalaludin Rahmat 2005,82)

Berdasarkan rumus tersebut maka ukuran sampelnya dapat dihitung sebagai beriut;

$n=\frac{180}{180(0.1)^{2}+1}=64,28$ dibulatkan menjadi 65 urang

Sample yang diambil adalah 65 orang.

\section{HASIL DAN PEMBAHASAN}

Kuesioner yang diberikan kepada responden, berupa pernyataan tertutup mengenai Literasi informasi masyarakat dalam pelaksanaan program desa mandiri pangan di Desa Mekarlaksana Kecamatan Cikancung Kabupaten Bandung. Setiap pernyataan yang diajukan, responden hanya perlu menjawab satu pilihan jawaban yang tersedia. Butir-butir pernyataan yang diajukan mengacu pada tolak ukur yang telah ditetapkan sebelumnya. Jawaban-jawaban yang tercantum dalam kuesioner mengacu pada skala likert. Pertanyaan yang ada dalam kuesioner masingmasing jawaban diberi skor sebagai berikut.

Tabel 2 Alternatif Jawaban Responden dan Skor Penilaian

\begin{tabular}{|l|c|c|}
\hline \hline Pilihan jawaban & \multicolumn{2}{|c|}{$\begin{array}{c}\text { Skor masing-masing } \\
\text { pernyataan }\end{array}$} \\
\cline { 2 - 3 } & $\begin{array}{l}\text { Pernyataan } \\
\text { positif }\end{array}$ & $\begin{array}{l}\text { Pernyataan } \\
\text { negatif }\end{array}$ \\
\hline Sangat tidak setuju & 1 & 5 \\
\hline Tidak setuju & 2 & 4 \\
\hline Tidak ada pendapat & 3 & 3 \\
\hline Setuju & 4 & 2 \\
\hline Sangat setuju & 5 & 1 \\
\hline & & \\
\hline
\end{tabular}

Setelah dilakukan uji validitas dan reliabilitas, selanjutnya adalah menganalisis data yang telah didapatkan dengan mengggunakan model analisis deskriptif. Model analisis ini menjelaskan pernyataan responden dengan mendeskripsikannya melalui penggunaan tabel dan pengukurannya menggunakan skala likert. Berdasarkan hal tersebut, maka jumlah skor dari seluruh responden adalah:

Tabel 3 Jumlah Skor Seluruh Responden

\begin{tabular}{|l|l|}
\hline Maksimal & 65 responden x 5 =325 \\
\hline Minimal & 65 responden x $1=65$ \\
\hline Median & 65 responden x $3=195$ \\
\hline Kuartil I & 65 responden x $2=130$ \\
\hline Kuartil III & 65 responden x 4 $=260$ \\
\hline
\end{tabular}

Jumlah skor tersebut kemudian dianalisis dengan menggunakan beberapa pendekatan (Sugiyono, 2008), untuk menentukan seberapa besar tingkat Literasi informasi masyarakat, sebagai berikut:

a. Jika Kuartil III < Skor < Maksimal; artinya sangat positif (Literasi informasi masyarakat dinilai aktif).

b. Jika Median < Skor < Kuartil III; artinya positif (Literasi informasi masyarakat dinilai cukup aktif).

c. Jika Kuartil I < Skor < Median; artinya negatif (Literasi informasi masyarakat dinilai kurang aktif).

d. Jika Minimal < Skor < Kuartil I; artinya sangat negatif (Literasi informasi masyarakat dinilai tidak aktif).

Apabila dipersentasekan, maka besar tingkat Literasi informasi masyarakat dapat dihitung berdasarkan rumusan sebagai berikut:

Skor yang diperoleh

Tingkat Literasi informasi = -----------------x 100

Skor maksimal 
Pada bagian ini akan diukur mengenai tingkat Literasi informasi masyarakat berdasarkan tolak ukur yang ada pada masing-masing variabel. Untuk mempermudah pengolahan data, data yang diperoleh kemudian diolah dengan menggunakan Microsoft Excel. Berikut adalah penjelasannya berdasarka kepada hasil nasilis terhadap masingmasing indicator dari setiap variabel penelitian.

\section{Literasi informasi dalam Pengambilan}

\section{Keputusan/ Perencanaan}

Variabel ini memiliki enam indikator yaitu a. Informasi mengenai program desa mandiri pangan didapatkan melalui kelurahan atau RT/RW setempat, b. Pemberitahuan mengenai adanya program desa mandiri pangan bagi masyarakat dilakukan secara jelas, c. Masyarakat mencari tahu lebih jauh mengenai program desa mandiri pangan, d. Pernah diajak musyawarah untuk membahas perencanaan program desa mandiri pangan, e Pernah memberikan masukan gagasan/ ide dalam program desa mandiri pangan, dan $\mathrm{f}$. Keterlibatan masyarakat dalam program desa mandiri pangan harus dari awal kegiatan sampai akhir kegiatan, Berikut adalah perhitungan dari tiap indicator/ tolak ukur tersebut:
Tabel 4 Literasi informasi dalam Pengambilan Keputusan/ Perencanaan

\begin{tabular}{|c|c|c|c|}
\hline No & Tolak ukur & Skor & Median \\
\hline 1 & $\begin{array}{l}\text { Informasi } \\
\text { mengenai } \\
\text { program desa } \\
\text { mandiri pangan } \\
\text { didapatkan } \\
\text { melalui } \\
\text { kelurahan atau } \\
\text { RT/RW } \\
\text { setempat }\end{array}$ & 287 & 195 \\
\hline 2 & $\begin{array}{l}\text { Pemberitahuan } \\
\text { mengenai } \\
\text { adanya program } \\
\text { desa mandiri } \\
\text { pangan bagi } \\
\text { masyarakat } \\
\text { dilakukan secara } \\
\text { jelas }\end{array}$ & 255 & 195 \\
\hline 3 & \begin{tabular}{ll}
\multicolumn{2}{l}{ Masyarakat } \\
mencari tahu \\
lebih & jauh \\
mengenai \\
program desa \\
mandiri pangan
\end{tabular} & 211 & 195 \\
\hline 4 & $\begin{array}{l}\text { Pernah diajak } \\
\text { musyawarah } \\
\text { untuk } \\
\text { membahas } \\
\text { perencanaan } \\
\text { program desa } \\
\text { mandiri pangan }\end{array}$ & 290 & 195 \\
\hline 5 & $\begin{array}{l}\text { Pernah } \\
\text { memberikan } \\
\text { masukan } \\
\text { gagasan/ ide } \\
\text { dalam program } \\
\text { desa mandiri } \\
\text { pangan Pernah } \\
\text { memberikan } \\
\text { masukan } \\
\text { gagasan/ ide } \\
\text { dalam program } \\
\text { desa mandiri } \\
\text { pangan }\end{array}$ & 265 & 195 \\
\hline 6 & $\begin{array}{l}\text { Keterlibatan } \\
\text { masyarakat } \\
\text { dalam program } \\
\text { desa mandiri } \\
\text { pangan harus } \\
\text { dari awal } \\
\text { kegiatan sampai } \\
\text { akhir kegiatan }\end{array}$ & 262 & 195 \\
\hline & Total & 1570 & 195 \\
\hline & Rata-rata & 261.66 & 195 \\
\hline
\end{tabular}


Data di atas menggambarkan bahwa Literasi informasi masyarakat dalam pengambilan keputusan/ Perencanaan program desa mandiri pangan cukup tinggi. Hal ini terlihat dari rata-rata skor yang diperoleh adalah 261, 66. Skor tersebut jauh lebih tinggi dari skor median yakni 195. Tingkat Literasi informasi ini terjadi disebabkan oleh keterbukaan para pengelola program desa mandiri pangan yang dimotori oleh pihat pemerintahan desa Mekarlaksana.

Apa bila diuraikan secara rinci dari masingmasing indikator/ tolak ukur maka dapat diuraikan bahwa pemberitahuan mengenai program desa mandiri pangan ini disampaikan secara terbuka oleh pemerintahan desa melalui tim pelaksana tingkat desa dan tingkat RW. Hal ini terlihat dari data mengenai perolehan informasi mengenai desa mandiri pangan oleh masyarakat mencapai skor 278. Skor ini hamper mencapai skor maksimmal yakni 325. Skor dari indikator lainnya pun tidak terlalu berbeda yakni a) Pemberitahuan mengenai adanya program desa mandiri pangan bagi masyarakat dilakukan secara jelas macapai skor 255, b) Masyarakat mencari tahu lebih jauh mengenai program desa mandiri pangan mencapai skor 211 , c) Pernah diajak musyawarah untuk membahas perencanaan program desa mandiri pangan mencapai sekor 290, d) Pernah memberikan masukan gagasan/ ide dalam program desa mandiri pangan mencapai skor 265, dan e) Keterlibatan masyarakat dalam program desa mandiri pangan harus dari awal kegiatan sampai akhir kegiatan mencapai skor 262.

Apabila skor komulatif dari sub variabel ini dipresentasekan maka dapat dihitung sebagai berikut:
261.66

Tingkat Literasi informasi V1= -----------x 100

$$
=80.51
$$

\section{Literasi informasi Masyarakat dalam Pelaksanaan Program}

Variabel ini memiliki empat indikator yaitu a) Alat usaha yang digunakan dalam menjalankan usaha adalah milik pribadi. b) Setiap kegiatan dalam program desa mandiri pangan selalu didokumentasikan c) Selalu ikut serta dalam pengadministrasian kegiatan d) Fasilitator sangat berperan dalam pendampingan kelompok. Berikut adalah perhitungan dari tiap indicator/ tolak ukur tersebut:

Tabel 5 Literasi informasi Masyarakat dalam Pelaksanaan Program

\begin{tabular}{|l|l|l|l|}
\hline No & Tolak ukur & Skor & Median \\
\hline 1 & $\begin{array}{l}\text { Alat usaha yang } \\
\text { digunakan dalam } \\
\text { menjalankan usaha } \\
\text { adalah milik } \\
\text { pribadi. }\end{array}$ & 247 & 195 \\
\hline 2 & $\begin{array}{l}\text { Setiap kegiatan } \\
\text { dalam program } \\
\text { desa mandiri } \\
\text { pangan selalu } \\
\text { didokumentasikan }\end{array}$ & 149 & 195 \\
\hline 3 & $\begin{array}{l}\text { Selalu ikut serta } \\
\text { dalam } \\
\text { pengadministrasian } \\
\text { kegiatan }\end{array}$ & 140 & 195 \\
\hline 4 & $\begin{array}{l}\text { Fasilitator sangat } \\
\text { berperan dalam } \\
\text { pendampingan } \\
\text { kelompok }\end{array}$ & 259 & 195 \\
\hline \multicolumn{2}{|c|}{ Total } & 795 & 195 \\
\hline \multicolumn{2}{|l|}{ Rata-rata } & 198.75 & 195 \\
\hline
\end{tabular}

Data di atas menggambarkan bahwa Literasi informasi masyarakat dalam pelaksanaan program desa mandiri pangan cukup tinggi. Hal ini terlihat dari rata-rata skor yang diperoleh adalah 198.75. 
Walaupun Skor tersebut tidak terlalu jauh dari skor median yakni 195. Berdasarkan data di atas dari empat indikator yang menjadi tolak ukur variabel ini dapat dipilah menjadi dua kelompok. Kelompok pertama menunjukkan skor diatas median dan kelompok kedua skor berada di bawah median.

Kelompok pertama yakni a) Alat usaha yang digunakan dalam menjalankan usaha adalah milik pribad memiliki skor 247, dan b) Fasilitator sangat berperan dalam pendampingan kelompok memiliki skor 259. Kelompok ini menggambarkan mengenai modal, tempat, dan alat usaha sebagian besar adalah milik dari anggota afinitas. Hal ini menggambarkan bahwa setiap anggota afinitas berusaha untuk terlibat dalam program desa mandiri pangan dengan melibatkan modal, tempat, dan alat usahanya sebagai bagian dari program tersebut. Oleh karena itu, data ini menujukkan betapa besarnya antusiasme masyarakat untuk ikut terlibat/ berLiterasi informasi dalam program ini.

Kelompok kedua yakni a) Setiap kegiatan dalam program desa mandiri pangan selalu didokumentasikan memiliki skor 149, b) Selalu ikut serta dalam pengadministrasian kegiatan memiliki skor 140. Apabila di kelompokan komponen-komponen yang termasuk pada kelompok ini adalah komponen adminitrasi dan komunikasi. Komponen administrasi berkaitan dengan proses pendokumentasian kegiatan dan pelaporan. Berdasarkan hasil wawancara dengan para anggota afinitas mereka menyatakan bahwa proses pengadministrasian itu sangat sulit. Apalagi proses pelaporan hasil kegiatan harus slalu lengkap.
Yang kedua adalah proses komunikasi antara anggota kelompok afinitas dengan pendamping atau fasilitator. Berdasarkan hasil wawancara dengan para anggota afinitas fasilitator sulit ditemui. Proses pendampingan tidak begitu lancar. Hal ini terjadi karena tersebarnya anggota kelompok afinitas di daerah-daerah yang sulit untuk dijangkau sehinggan koordinasi sulit dilaksanakan secara efektif. Selain itu, kesibukan anggota afinitas dan pendamping juga berpengaruh terhadap kelancaran komunikasi diantara mereka.

Anggota afinitas pada umumnya adalah petani dan peternak. Keseharian mereka lebih banyak di kebun dan sawah. Mereka baru berada di rumah atau menjalankan aktifitas lainnya diatas pukul 4 sore, padahal para pendampig dating siang hari sekitar pukul 12-an.

Apabila skor komulatif dari sub variabel ini dipresentasekan maka dapat dihitung sebagai berikut:

$$
\begin{gathered}
\text { Tingkat Literasi informasi } \text { V2 }=\frac{198.75}{325} \\
=61.15 \%
\end{gathered}
$$

\section{Literasi informasi Masyarakat dalam}

\section{Pengambilan Manfaat}

Variabel Literasi informasi masyarakat dalam pengambilan manfaat memiliki 4 indikator. Keempat indikator tersebut adalah a) Kemudahan dalam permohonan pengajuan program desa mandiri pangan, b) Kemudahan prosedur dalam mendapatkan modal usaha dari program desa mandiri pangan, c) Adanya program desa mandiri pangan membantu pemecahan masalah usaha yang dihadapi anggota, dan d) Keterampilan anggota kelompok menjadi meningkat dengan 
pendampingan yang diberikan. Berikut adalah perhitungan dari tiap indicator/ tolak ukur tersebut:

Tabel 6 Literasi Informasi Masyarakat dalam Pengambilan Manfaat

\begin{tabular}{|c|c|c|c|}
\hline No & Tolak ukur & Skor & Median \\
\hline 1 & $\begin{array}{l}\text { Adanya } \\
\text { program desa } \\
\text { mandiri pangan } \\
\text { membantu } \\
\text { pemecahan } \\
\text { masalah usaha } \\
\text { yang dihadapi } \\
\text { anggota }\end{array}$ & 279 & 195 \\
\hline 2 & $\begin{array}{l}\text { Keterampilan } \\
\text { anggota } \\
\text { kelompok } \\
\text { menjadi } \\
\text { meningkat } \\
\text { dengan } \\
\text { pendampingan } \\
\text { yang diberikan }\end{array}$ & 251 & 195 \\
\hline & Total & 530 & 195 \\
\hline & Rata-rata & 265 & 195 \\
\hline
\end{tabular}

Data di atas menggambarkan bahwa Literasi informasi masyarakat dalam pengambilan manfaat program desa mandiri pangan cukup tinggi. Hal ini terlihat dari rata-rata skor yang diperoleh adalah 265. Skor tersebut cukup jauh dari skor median yakni 195. Indikator 1. Adanya program desa mandiri pangan membantu pemecahan masalah usaha yang dihadapi anggota memilki skor 279, dan 2. Keterampilan anggota kelompok menjadi meningkat dengan pendampingan yang diberikan memiliki skor 251 . Indikator ini menunjukkan Literasi informasi masayarakat cukup tinggi. Hal ini terkait dengan permasalahan pokok yang dihadapi oleh para angota afinitas. Permasalahan utama kelompok afinitas adalah kemampuan sumberdaya manusia dan modal usaha. Dengan adanya program desa mandiri pangan ini kedua masalah tersebut teratasi.

Menurut pera responden, dengan adanya program desa mandiri pangan permasalahan sumberdaya manusia dan permodalan sedikit teratasi. Melalui program ini masyarakat bisa meningkatkan pengetahuan dan keterampilanya sesuai dengan bidang usaha masing-masing, karena dalam program ini ada pelatihan-pelatihan yang diberikan oleh para fasilitator atau pendamping. Bagitu pun dengan permodalan, melalui program ini permodalan para anggota sangat dibantu. Namun, berkaitan dengan permodalan ini yang menjadi kesulitannya adalah prosedur pengajuan bantuan keuangan dan administrasi pertanggung jawaban. Hal ini terlihat dari hasil perhitungan angket yang menggambarkan kedua masalah tersebut sulit buat para anggota afinitas. Data tersebut dapat dilihat pada kelompok kedua.

Apabila skor komulatif dari sub variabel ini dipresentasekan maka dapat dihitung sebagai berikut:

$$
\begin{gathered}
\text { Tingkat Literasi informasi } \quad \text { V3= ----------x } 100 \\
=81.53
\end{gathered}
$$

\section{Literasi informasi Masyarakat dalam evaluasi}

Variabel Literasi informasi masyarakat dalam kegiatan evaluasi memiliki dua indikator. Keenam indicator tersebut adalah a) Selalu memberi masukan kepada pengelola program pada akhir pelaksanaan kegiatan Program desa mandiri pangan di Desa Mekarlaksana Kec. Cikancung Kabupaten Bandung sangat baik dan tepat sasaran, b) Membantu pengumpulan data/ 
bahan pelapran kegiatan Program desa mandiri pangan di Desa Mekarlaksana Kec. Cikancung Kabupaten Bandung.

Tabel 7 Literasi informasi Masyarakat dalam Evaluasi

\begin{tabular}{|l|l|l|l|}
\hline No & Tolak ukur & Skor & Median \\
\hline 1 & $\begin{array}{l}\text { Selalu memberi } \\
\text { masukan kepada } \\
\text { pengelola } \\
\text { program pada } \\
\text { akhir } \\
\text { pelaksanaan } \\
\text { kegiatan }\end{array}$ & 248 & 195 \\
\hline 2 & $\begin{array}{l}\text { Membantu } \\
\text { pengumpulan } \\
\text { data/ bahan } \\
\text { pelapran } \\
\text { kegiatan }\end{array}$ & 251 & 195 \\
\hline \multicolumn{2}{|l|}{ Total } & 499 & 195 \\
\hline \multicolumn{2}{|l|}{ Rata-rata } & 249.5 & 195 \\
\hline
\end{tabular}

Data di atas menggambarkan bahwa Literasi informasi masyarakat pada tahap evaluasi program desa mandiri pangan cukup tinggi. Hal ini terlihat dari rata-rata skor yang diperoleh adalah 249.5. Skor tersebuh jauh lebih tinggi dari skor median yakni 195 bahkan masih melebihi skor kwartil III yakni 260. Tingkat Literasi informasi ini muncul disebabkan oleh pelaksanaan program yang tepat sasaran, pergram ini sangat bermanfaat, dan program ini dijalankan secara bersama-sama oleh masyarakat dan pemerintah.

Apabila lihat berdasarkan tolak ukur yang digunakan dapat digambarkan sebagai berikut; a) Selalu memberi masukan kepada pengelola program pada akhir pelaksanaan kegiatan Program desa mandiri pangan di Desa Mekarlaksana Kec. Cikancung Kabupaten Bandung sangat baik dan tepat sasaran memiliki skor 248. b) Membantu pengumpulan data/ bahan pelapran kegiatan Program desa mandiri pangan di Desa Mekarlaksana Kec. Cikancung Kabupaten Bandung memiliki skor 251. Berdasarkan hasil wawancara dengan para responden bahwa masyarakat yang bisa menjadi anggota afinitas harus diseleksi dan disesuaikan dengan kriteria yang telah ditetapkan oleh pemerintan. Jadi tidak bias sembarang orang menjadi anggota afinitas. Hal ini sejalan dengan buku pedoman desa mandiri pangan. Di dalam buku tersebut dinyatakan bahwa "Kelompok usaha adalah masyakarat yang mengembangkan usaha secara bersama-sama dan memiliki komoditas sejenis, yang mengarah pada pembentukan cluster. Kelompok usaha ditumbuhkan oleh FKK, LK, dan masyarakat. Kelompok ditetapkan melalui Keputusan Kepala Badan/Dinas/Kantor/unit kerja Ketahanan Pangan Kabupaten/Kota.”

Apabila skor komulatif dari sub variabel ini dipresentasekan maka dapat dihitung sebagai berikut:

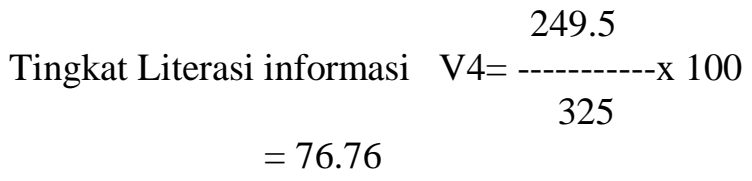

Berdasarkan skor komulatif dari masingmansing sub variabel maka tingkat literasi informasi masyarakat dalam program desa mandiri pangan dapat dikelompokkan menjadi dua bagian. Bagian pertama yakni pertisipasi masyarakat dalam pengambilan keputusan/ perencanaan dan pengambilan manfaat adalah sangat positif. Hal ini karena Kuartil III < Skor < Maksimal; artinya sangat positif (Literasi informasi masyarakat dinilai aktif). Hal ini dapat dilihat pada tabel di bawah ini. 
Tabel 8 Perhitungan Skor Komulatif Setiap Sub Variabel

\begin{tabular}{|c|c|c|c|c|c||}
\hline SubVariabel & $\begin{array}{c}\text { Kuartil } \\
\text { III }\end{array}$ & & Skor & & $\begin{array}{c}\text { Nilai } \\
\text { Maksimal }\end{array}$ \\
\hline $\begin{array}{c}\text { Pengmbilan } \\
\text { keputusan }\end{array}$ & 260 & $<$ & 261.66 & $<$ & 325 \\
\hline $\begin{array}{c}\text { Pengambilan } \\
\text { manfaat }\end{array}$ & 260 & $<$ & 265 & $<$ & 325 \\
\hline
\end{tabular}

Bagian kedua yakni Literasi informasi masyarakat dalam pelaksanaan program dan pengambilan adalah positif. Hal ini karena

Median < Skor < Kuartil III; artinya positif (Literasi informasi masyarakat dinilai cukup aktif). Hal ini dapat dilihat pada tabel berikut ini:

Tabel 9 Perhitungan Skor Komulatif Setiap Sub Variabel

\begin{tabular}{|c|c|c|c|c|c|}
\hline Sub Variabel & Median & & Skor & & $\begin{array}{c}\text { Kuartil } \\
\text { III }\end{array}$ \\
\hline $\begin{array}{c}\text { Pelaksanaan } \\
\text { program }\end{array}$ & 195 & $<$ & 198.75 & $<$ & 260 \\
\hline Evaluasi & 195 & $<$ & 249.5 & $<$ & 260 \\
\hline
\end{tabular}

Apabila skor komulatif dari variabel ini dihitung maka Literasi informasi masyarakat dalam program desa mandiri pangan adalah positif. Hal ini terlihat dari Median < Skor < Kuartil III artinya positif (Literasi informasi masyarakat dinilai cukup aktif). Hal ini dapat dilihat pada tabel berikut ini:

Tabel 10 Perhitungan Skor Kumulatif Variabel

\begin{tabular}{|c|c|c|c|c|c|}
\hline Variabel & Median & & Skor & & $\begin{array}{c}\text { Kuartil } \\
\text { III }\end{array}$ \\
\hline $\begin{array}{c}\text { Literasi } \\
\text { informasi } \\
\text { masyarakat }\end{array}$ & 195 & $<$ & 243.73 & $<$ & 260 \\
\hline
\end{tabular}

Apabila skor komulatif ini dipresentasekan maka dapat dihitung sebagai berikut:

$\begin{array}{cc}\text { Tingkat Literasi informasi } & V=-\begin{array}{c}243.73 \\ \end{array} \\ =74.99 & 325\end{array}$

\section{SIMPULAN}

Berdasarkan hasil pengolahan data dan analisis deskriptif, penelitian ini dapat disimpulkan bahwa Tingkat Literasi informasi Masyarakat Pada Program Desa Mandiri Pangan Di Desa Mekarlaksana Kec.Cikancung Kabupaten Bandung adalah positif. Hal ini terlihat dari Median < Skor < Kuartil III artinya positif (Literasi informasi masyarakat dinilai cukup aktif).

\section{DAFTAR PUSTAKA}

Arikunto, Suharsimi. (2010). Prosedur Penelitian Suatu Pendekatan Praktik. Jakarta: Rineka Cipta.

Barker, Chris. et. al. (2002). Research Methods in Clinical Psychology: An Introduction for Students and Practitioners Wiley \& Sons. London

Data Dasar Rumahtangga (DDRT) Desa Mandiri Pangan. (2006). Badan Ketahanan Pangan. Dep. Pertanian RI. Jakarta.

Evaluasi kegiatan Program Aksi Desa Mandiri Pangan (PROKSI DESA MAPAN). (2009). Badan Ketahanan Pangan.

Nurfaizah, Eva. (2013). Implementasi Pemberdayaan Masyarakat Sebagai Upaya Pengentasan Kemiskinan Melalui Program Aksi Desa Mandiri Pangan Di Desa Karangkepoh, Kecamatan Karanggede, Kabupaten Boyolali. Semarang; Ikip PGRI.

Pedoman Umum Program Aksi Desa Mandiri Pangan (Desa Mapan). (2009). Badan Ketahanan Pangan Badan Ketahanan Pangan, Dep. Pertanian RI. Jakarta. 
Pedoman Umum Program Aksi Desa Mandiri Pangan (Desa Mapan). (2012). Badan Ketahanan Pangan Badan Ketahanan Pangan, Dep. Pertanian RI. Jakarta.

Poewanto, Hari. (2000). Kebudayaan dan Lingkungan dalam Perspektif Antropologi. Cetakan I. Yogyakarta: Pustaka Pelajar

Rohidi, Tjetjep Rohendi. (2000). Ekspresi seni orang miskin: Adaptasi simbolik terhadap kemiskinan. Bandung. Nuansa cendikia.

Safi'i, M. (2011). Ampih Miskin, Model Kebijakan Penuntasan Kemiskinan dalam Perspektif Teori dan Praktek. Cetakan 1. Averroes Press. www.averroespress.net.

Soetomo. (2012). Pemberdayaan Masyarakat Mungkinkah Muncul Antitesisnya. Yogyakarta: Puataka Pelajar.

Sugiyono. (2008). Metode penelitian kuantitatif kualitatif dan $R \& D$. Bandung: Alfabeta.

Sugiyono. (2008). Metode Penelitian Bisnis. Bandung. Alfabeta

Supardi. (1979). Statistik. Bandung: Fakultas Tarbiyah, IAIN Sunan Gunug Jati.

Sutopo. HB. (2006). Metode Penelitian Kualitatif, Surakarta: UNS Press.

Yusup, Pawit M. (2013). Perilaku Pencarian Informasi Penghidupan Pada Penduduk Miskin Pedesaan. Bandung: Universitas Padjadjaran. 
